\title{
Regional Disparities: Analysis of Policy Responses Towards Educational Inequalities in Cameroon
}

\author{
Mathias Guiake \\ Institute of International and Comparative Education, Zhejiang Normal University, \\ 688 Yingbin Avenue, Jinhua City, Zhejiang Province 321004, China
}

\begin{abstract}
The rise of regional inequalities within countries, especially in developing countries, has been a heated discussion topic among scholars and political leaders. They significantly increase even though, both nationally and internationally, studies show a slight decline in the poverty rate among the population. This study, therefore, explores inequalities in the education sector and policy responses that address those disparities by focusing specifically on Cameroon. The study explores existing literature, conceptual frameworks and statistical data to highlight inequalities in education in Cameroon. It also examines different perspectives of social inequalities and policy responses in some selected countries in order to find out the best policies and strategies to address regional inequalities in education in Cameroon. The analysis finds out that despite the existence of a huge gap between lagging behind northern regions and other regions, little appropriate has been done regarding policy responses to overcome regional disparities in the education sector. Inequalities in education access, resource provision and quality education between regions are tremendously phenomenal, and it has progressively widened. The education access and provision of resources do not take into consideration the needs and the complexity of each region. Therefore, the study recommends effective special policies regarding the development of infrastructures and the supply of human resources in underserved regions.
\end{abstract}

Keywords: Regional Inequality, Education, Policy, Social Justice, Cameroon

DOI: $10.7176 / \mathrm{DCS} / 10-3-07$

Publication date:March $31^{\text {st }} 2020$

\section{Introduction}

Cameroon is a lower-middle-income country with a Gross National Income (GNI) per capita evaluated at US\$ 1,357 in 2016 (World Bank, 2018). The average economic growth has slowed down from 6 per cent in 201415 to 3.7 per cent in 2017 (World Bank, 2018). A population estimated at 23.3 million people in 2015. Thanks to its rich natural resources, and its population relatively well-educated (Guiake and Zhang, 2019), Cameroon has a great opportunity for rapid socio-economic development. However, despite these resources, Cameroon remains undeveloped and a low-income country, with about $37 \%$ of the population living below the poverty line (World Bank, 2018). As in many countries, especially in developing countries in which not only regional disparities but also social class, ethnic and gender disparities are so huge, Cameroon is far to be an exception. In multiethnic societies, namely in African countries, the issue of inequalities or the desire to build an 'inclusive nation' (in which living-together is possible) has posed since the period of independences. In Cameroon for instance, the government has introduced the policy of regional quotas (regional equilibrium) to access into public services in order to ensure equity and social justice between various ethnic groups (Som-I, 2018). The administrative division, such as regions, are quite divided according to the different hub of ethnic groups. That is the reason why the policy is considered as "ethnicity balance policy". The presidential decree no 82/407 on September 7, 1982, amending that of No $75 / 496$ of July 3,1975 , stipulates that the distribution of places into public service from competitive examinations takes into account the region of origin of the candidates' parents (Yodou Sibeudeu, 2011). Each region has a precise percentage of place in those national recruitments into public service. Later on, the decree was adjusted by the decision no 0015/MINFOPRA/Cab on August 20, 1992, following a new change in the administrative division in which Cameroon counts ten regions (called provinces at that time) instead of 7 like before (Som-I, 2018). The decision adjusts the quota distribution from 7 into ten regions. As said, that regional equilibrium aimed to build the unity of the country and to create a peaceful environment by representing every social group into the civil and military service. It allows to solve inequality challenges because some candidates come from regions with high schooling rate, but others do not. The policy is a kind of positive discrimination with regard to those coming from lagging behind regions, such as the three northern regions. However, even if this policy is to appreciate because it relieves some social and political tensions, it does not address the real causes of those inequalities. There is a need for a policy that would raise the standards of less developed regions in both education and other areas.

"Poverty is disproportionately concentrated in rural areas and the northern regions of the country" (World Bank, 2018). According to the World Bank (2016, 2018), 56 per cent of all poor people in Cameroon live only in the three northern regions. The report noticed that the contrast between northern and southern part of Cameroon is so huge. The northern regions per capita consumption declined since 2001 by 15 per cent while it increased in the south by nearly 50 per cent (World Bank, 2016). 
Speaking of the developing countries in general, Rew (2008) argued that the intensification of disparities in this part of the world is mostly due to an unequal distribution of the benefits of economic growth and poverty reduction. In Addition to the unequal distribution of benefits, which can partly explain regional disparities in developing countries, in Cameroon unfortunately, so many other factors such as natural factors (spatial location, climatic conditions, and inadequate productive assets) and social factors (demographic capital, and instability due to the terrorist crises) have a significant contribution to the regional disparities. According to the World Bank reports $(2016,2018)$, the northern regions of Cameroon especially the Far-North and North regions belong to Sudano-Sahelian climatic zone where it only rains hardly five months a year (from May to September), with a long dry season lasting six to seven months (October to April). It is the most environmentally fragile zones in Cameroon where the erosion is very frequent and widespread during raining seasons. The northern regions live essentially from the agricultural revenue, and the agricultural activities face lots of challenges such as the use of traditional methods, the scarcity of rains, the tensions between pastoralists and crop farmers, and the bush fire.

Moreover, the northern regions are the furthest from the coastal part where economic activity is more flourished. There is a lack of adequate transportation, sanitation service (only $14.3 \%$ of the population in the FarNorth region have access to the sanitary infrastructure (UNDP, 2016)), educational infrastructures, and electricity services (only $47 \%$ coverage rate compared to $88 \%$ in other regions (World Bank, 2018)). Furthermore, the northern part, particularly the Far-North region has suffered since 2014 from the Boko Haram terrorist group which has been perpetuating insecurity and violence causing thousands of deaths and internal displacement, affecting negatively education progress and slowing down economic activities. Alongside with that, the insecurity in the Central African Republic and escalating violence in Nigeria have pushed thousands of refugees from these countries to seek refuge in the Far-North region (UNDP, 2016).

All those factors listed, explain the reasons for the huge regional disparity in Cameroon both in education and in other domains.

The study employs document exploratory method. Documents include government policy materials, yearly statistics released from the Ministries of Education and from other educational institutions, reports, and existing scholarly literature. Data from those documents provide a deep understanding of regional inequality in education in Cameroon. They also inform us about other countries' various social disparities and related policy responses dealing with those inequalities, especially in the education sector. Based on the insight from the documents' exploration, recommendations and concluding remarks have been provided in order to effectively bridge the huge gap in education between northern regions and the other regions in Cameroon.

\section{Review of Literature}

The gap in education as well as in other domains between rich and poor people, between majority and minority groups, between male and female, urban and rural areas, especially in developing countries has been becoming wider over time. For this reason, many international and national organisations, and state governments have made equality and equity a big preoccupation in this $21^{\text {st }}$ century. Inequality and inequity issues are one of the main preoccupations of those organisations and governments because without eradicating or reducing them, many of those agencies and government's objectives to reach sustainable development and shared prosperity will not be attained. For Stewart (2013), there is a close link between inequality and poverty. Stewart argued that the higher the inequality, the higher the poverty rate. An equitable education system can redress the effect of a large socioeconomic inequality and can contribute to the economic competitiveness and social cohesion (OECD, 2012). Equality according to Holsinger and Jacob (2008) is the state of being equal in terms of quantity, rank, status, value, or degree. And, Grisay (1984) identified five tenets of educational equality, namely "natural equality, educational of access principle, equality of treatment principle, equality of achievement principle, and the postmodern principle" (Hawkins et al., 2008). Unlike from equality, equity takes into account social justice ramifications in relation to the fairness, justness between people. The equity is based on the idea of moral equality, referring to how each individual should be treated according to their differences; it is not the same as treating people equally (Jones, 2009).

Equal treatment is good because it does not discriminate any group. It treats equally and provides the same amount, value and attention to different groups; which is not bad. However, equality becomes unfair when, from the beginning, groups already present differences. Providing the same treatment to different groups when differences already exist, ensures the perpetuation of initial inequalities. At this point, equity becomes very important at compensating differences. In education, for instance, equity acknowledges the existence of unequal treatment; it compensates the level of the groups from disadvantaged educational backgrounds or areas (Castelli et al., 2012). Equity, according to Benadusi cited in Castelli et al. (2012), is the problematisation and relativisation of the concept of equality, which in the past has often been articulated in a non-problematic manner. Equity is a very critically controversial concept which from advantaged groups, it consists of favouring disadvantaged people. To them, it is not equal, and consequently 'unfair' when some groups are treated well over others. According to Stewart (2013), the determination of what is right, just or equitable distribution is one of the most critical questions 
because people have different point of views on it. Equity treatment becomes controversial when it comes, for example, to the practices such as the admission to the educational institutions (which is, of course, one practice among many others). Less performant students can be admitted over those who performed better because of their disadvantaged situation. Taking a situation on students in which the admission in some institutions is set according to the scores gotten in the national examination, and the scores are set differently according to the regions, gender or ethnic groups. Let us say a student " $\mathrm{A}$ " is from an advantaged area or advantaged ethnic group. He got a score of 80 out of 100 . A student "B" is from a disadvantaged area or minority group. He got 60 out of 100 . If the student " $B$ " because of his/her disadvantaged origin gets admission and the student " $A$ " does not, this latter will take such a treatment as an injustice. The treatment of inequality at the end of the educational process, to mention the case of education, is very often full of clashes. Therefore, the concept of equity is very controversial.

However, whatever it is said about the fairness and justice of equity, it is a means of avoiding tensions in an unequal society and for shared prosperity. Many scholars and organisations agree that it enables the reduction of inequalities, and contributes to shared prosperity. An OECD report (2012) stated that the best performing education systems across OECD countries are those that merge quality and equity because students from low socioeconomic background have twice low performance compared to their pairs from the high socioeconomic background. For instance, a study conducted by Checchi \& Peragine (2005) on PISA results in 2000 in Italy found that there were substantial differences across macro-regions; the average score in high school in North-Western (developed) regions was 572 while it was 503 in the South (less developed regions). The study found the reasons of those differences in community and parents educational background. The OECD report (2012) argues that fair societies are the societies that respond to the current and future potential social, economic and even political crises.

Depending on each country's denomination, equity practices refer to "positive discrimination" or "affirmative action" which consists of treating a disadvantaged group better than advantaged one in order to raise their level. In education, equity treatment includes various practices which can be provided either at the beginning (inputs) or at the arrival line (outputs) of any educational activity.

Affirmative action, which is widely practised in many countries originated from compensatory justice. The theory of compensation justice stands for the idea that a victim of injustice should be compensated (by the perpetrator). It applied to a situation in which both victim and perpetrator are identified, and the perpetrator pays for his/her harm to the victim for compensation. The "compensatory justice refers to the provision of resources to a victim of injustice intending to minimize or reverse the impact of harm done by the injustice" (Mullen and Okimoto, 2015).

Studies show that today's affirmative action practices are an extension of the theory of compensatory justice. In affirmative action, the victims of injustice are not single individuals, but a group of people or a community. Compensatory justice, as well as affirmative action, seeks for the correction of the past or present injustices imposed by some people on others. It then provides necessary resources to the latter to establish justice. Equity practices are applied not only for injustices caused by individuals but also by nature itself because the nature sometimes is the root of injustice.

\section{Regional inequalities in education in Cameroon}

As aforementioned, the regional disparity in Cameroon, namely the three northern regions (Far-North, North and Adamawa) versus southern regions is very huge. It mainly results from the combination of unequal distribution of the benefits of economic growth and some natural and social circumstances. Together, they affect all sectors of life, especially the education sector. The education sector is particularly very affected, both regarding access, quality and students' performance. Education is, yet, very crucial in shaping human capital able to reduce poverty, inequalities, and to sustain the development. Several leading agencies have found education inequality and inequity as one of the main challenges in this $21^{\text {st }}$ century (Hawkins et al., 2008). Education is a drive for sustainable development. The importance of education in human lives is known by everyone, that no one would like to see some citizens in very deplorable educational conditions while others are not. Inequalities in education need to be paid serious attention in order to have shared prosperity among all citizens. The 2030 UNESCO Agenda highlights the relevance of addressing the rising inequalities within and between countries; it, therefore, works to promote inclusive and quality education for all, narrows the science and knowledge gaps between people; and develops inclusive public policies for social inclusion (UNESCO, 2017). The 2030 UNESCO Agenda requires education to empower people with knowledge, skills and values to live in dignity, build peaceful lives and contribute to their societies (UNESCO, 2019a).

As means of empowering people with knowledge and skill to develop their societies, education attainment in the northern regions of Cameroon is, unfortunately very low. The figure 1 below presents the educational attainment in the whole country in 2014 with $60,8 \%$ of the population in the Far-North, $46.2 \%$ in the North and $31.2 \%$ in Adamaoua did not attend even the primary school. The constitute the hub of non-schooling population in the country. 
Figure 1: Educational attainment by region in 2014

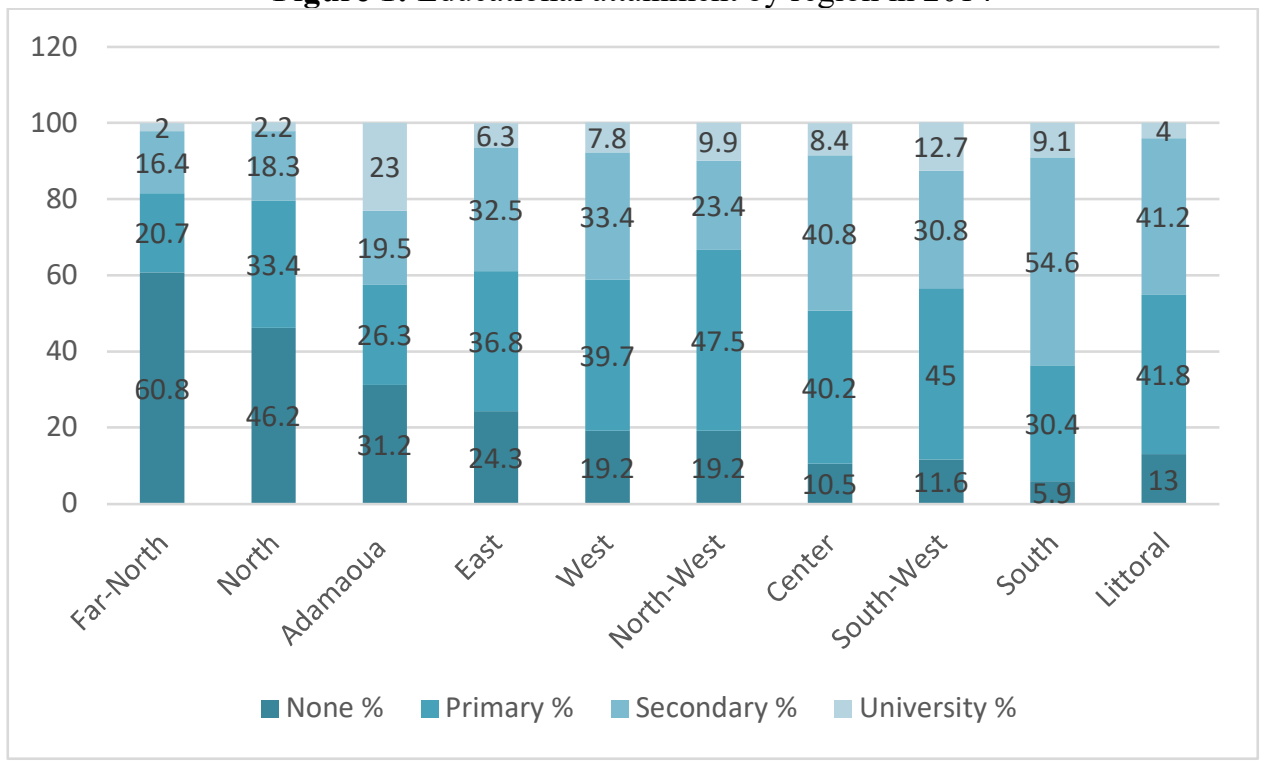

Source: World Bank, 2016. Republic of Cameroon: Priorities for ending poverty and boosting shared prosperity.

Systematic country diagnostic

Conscious of the huge regional inequalities in Cameroon and worried about being left behind by 2030 (date of eliminating any disparities within and between world's population, according to the 2030 UNESCO Agenda), this section examines four aspects, namely teachers, educational infrastructures, teaching and learning materials, and finally students achievement so as to show the considerable gap between Northern and Southern regions.

According to many scholars, teachers play a very crucial role in education. They are one of the most influential and powerful forces for equity, access and quality in education and key for a sustainable global development UNESCO (2019b). However, in Cameroon, teachers are unequally distributed. The northern regions, compared to other regions, have a severe dearth of teachers, especially in the Far North region. In 2010, a World bank report revealed that in the Far North region, the PTR (Pupil Teacher Ratios) had reached 104/1 (World Bank, 2010). The northern regions, due to their underdevelopment and extreme poverty, are the regions not desired by teachers, but where there is the greatest need. First of all, the number of teachers sent in these regions does not meet the need of schools. The demand is tremendously higher than the supply.

Figure 2: Pupil-teacher ratio by region (2014)

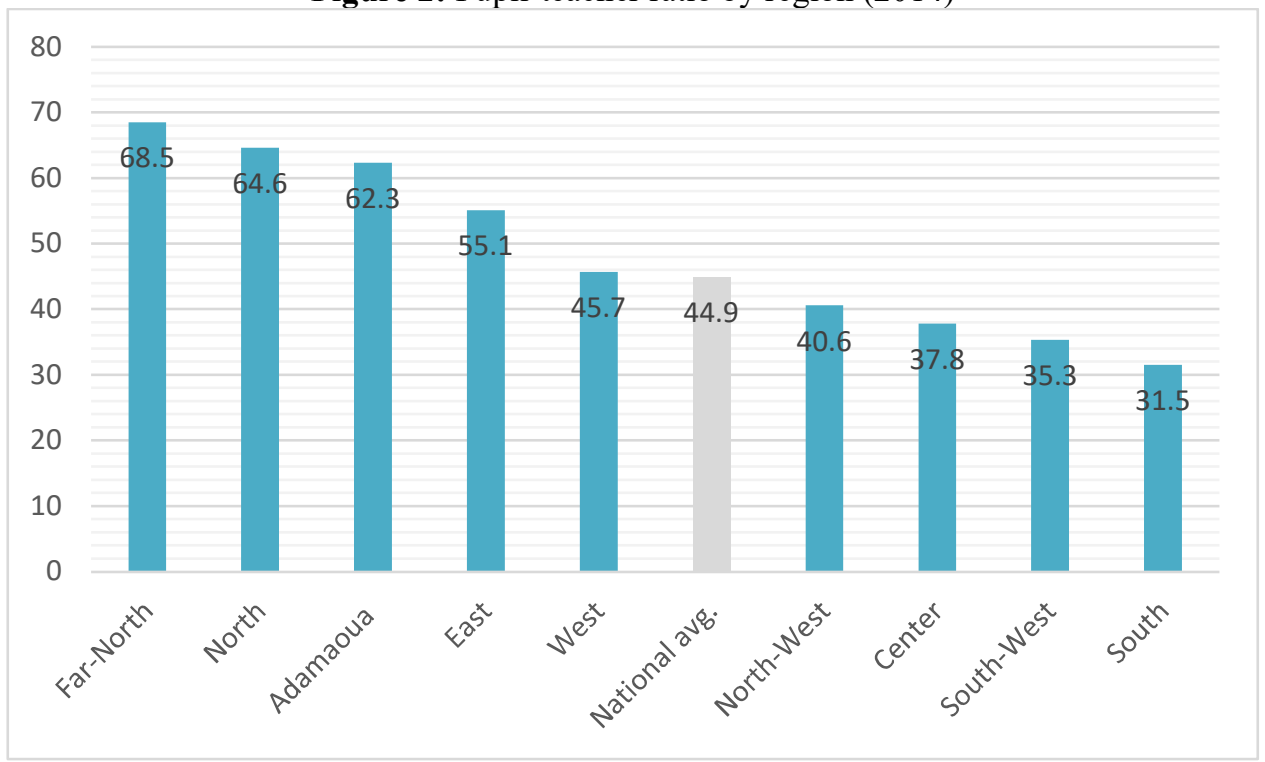

Source: World Bank, 2016. Republic of Cameroon: Priorities for ending poverty and boosting shared prosperity. Systematic country diagnostic

According to the last general population census, the Far North region is one of the most populated regions, and consequently where the need is high. Secondly, among the small number recognised by the government as teachers working in those regions, many of them are not going because of the adverse working conditions. Many 
teachers deployed in those regions just come back after they signed their presence in the school. They never go back for the service. Others spend some times then abandon their service. Other teachers are characterised by their absenteeism. They are not regularly at school. Regarding the issue of absenteeism and service abandonment, for instance, the governor of the Far-North region has released on March 27, 2019, an announcement revealing 600 cases of irregular absenteeism and post abandonment in which the majority concern primary and secondary school teachers (Kazé, 2019). The big paradox is that while northern regions have an acute lack of teachers, other regions sometimes possess a surplus of teachers. The central government distributes teachers all over the country, and most of the time without taking into account teachers' choice regarding neither the school nor the region they want to teach in. More importantly, there is no monetary incentives or other kinds of motivation to encourage teachers to work in those unwanted areas.

Regarding inequalities related to the lack of educational infrastructures, teaching and learning materials, again, the northern regions have been experiencing the dearth of educational infrastructures, teaching and learning materials making education access, quality and outcome unequal compared to other regions. Teacher absenteeism and abandonment are sometimes due to the bad conditions of teaching in schools. The challenges in school, both in the secondary education as well as in the primary, concern the shortage of schools, inappropriate school buildings, teaching classrooms, scarcity of textbooks, and other teaching and learning stuffs. Schools, especially secondary schools, are so far from each other. Students cover kilometres of distance to reach the nearest school; and as a result, a high rate of lateness and an increasing rate of absenteeism and drop out.

Regarding textbooks and learning materials, most of the students only rely on courses taught in the classroom by the teachers. They not only do not have additional materials to support the understanding of the lessons but most dangerously do not have required textbooks for classroom activities. Yet, at the end of their cycle, they will all together attend the same national examination paper with those who are in developed areas and big metropolises, where they have everything such as learning materials and qualified teachers at their disposal.

In addition to the challenges of learning infrastructures and teaching materials what teachers and students face in school, difficulties outside school are also plentiful. Among many of them, there is a dearth of basic services such as electricity and drinking water. As we mentioned above, the coverage in electricity in the northern regions is only $47 \%$ compared to $88 \%$ in other regions. In many localities, teachers and students only work during the day because, after sunset, there is no way to prepare or study lessons due to the lack of electricity. Moreover, people have to cover long distances to get water, either for domestic needs or for drinking. In some remote areas, they line up hours before getting water. The conditions are so difficult that the rate of school dropout is very high, and teachers deployed in such areas cannot stay long. Students who endure these different challenges can hardly perform well at school. As proof, the yearly released results from various national examinations show a low performance of students from the northern regions (see table and figure 3,4,5).

Table 1: Statistics of the baccalaureate exam results of the general secondary education, year: 2018, 2017, 2016 and 2015 (Success rate (\%) and Ranking).

\begin{tabular}{|l|l|l|l|l|l|l|l|l|}
\hline Regions & $\begin{array}{l}2018 \text { Success } \\
\text { rate (\%) }\end{array}$ & Rkg & $\begin{array}{l}2017 \\
\text { Success } \\
\text { rate (\%) }\end{array}$ & Rkg & $\begin{array}{l}2016 \\
\text { Success } \\
\text { rate (\%) }\end{array}$ & Rkg & $\begin{array}{l}2015 \\
\text { Success } \\
\text { rate (\%) }\end{array}$ & Rkg \\
\hline Centre & 53.01 & $6^{\text {th }}$ & 49.20 & $2^{\text {nd }}$ & 57.41 & $3^{\text {rd }}$ & 59.32 & $4^{\text {th }}$ \\
\hline Littoral & 57.00 & $4^{\text {th }}$ & 48.99 & $3^{\text {rd }}$ & 58.09 & $2^{\text {nd }}$ & 61.01 & $2^{\text {nd }}$ \\
\hline North-West & 60.83 & $2^{\text {nd }}$ & 57.82 & $1^{\text {st }}$ & 52.86 & $4^{\text {th }}$ & 67.31 & $1^{\text {st }}$ \\
\hline South-West & 59.77 & $3^{\text {rd }}$ & 41.30 & $7^{\text {th }}$ & 60.00 & $1^{\text {st }}$ & 45.04 & $9^{\text {th }}$ \\
\hline West & 54.03 & $5^{\text {th }}$ & 48.06 & $4^{\text {th }}$ & 50.67 & $7^{\text {th }}$ & 59.73 & 3 th \\
\hline South & 50.50 & $7^{\text {th }}$ & 45.84 & $5^{\text {th }}$ & 48.82 & $8^{\text {th }}$ & 54.00 & $6^{\text {th }}$ \\
\hline Est & 62.19 & $1^{\text {st }}$ & 39.03 & $9^{\text {th }}$ & 50.80 & $6^{\text {th }}$ & 57.34 & $5^{\text {th }}$ \\
\hline Adamaoua & 46.75 & $8^{\text {th }}$ & 42.72 & $6^{\text {th }}$ & 51.32 & $5^{\text {th }}$ & 49.21 & $7^{\text {th }}$ \\
\hline North & 42.53 & $9^{\text {th }}$ & 39.13 & $8^{\text {th }}$ & 40.44 & $9^{\text {th }}$ & 49.07 & $8^{\text {th }}$ \\
\hline Far-North & 34.95 & $10^{\text {th }}$ & 33.42 & $10^{\text {th }}$ & 35.42 & $10^{\text {th }}$ & 44.52 & $10^{\text {th }}$ \\
\hline Total & 51.74 & 1 & 46.13 & 1 & 52.72 & $/$ & 57.14 & $/$ \\
\hline
\end{tabular}

Source: Data imported from OBC: Office du Baccalauréat du Cameroun (National body in charge of secondary school examinations). 


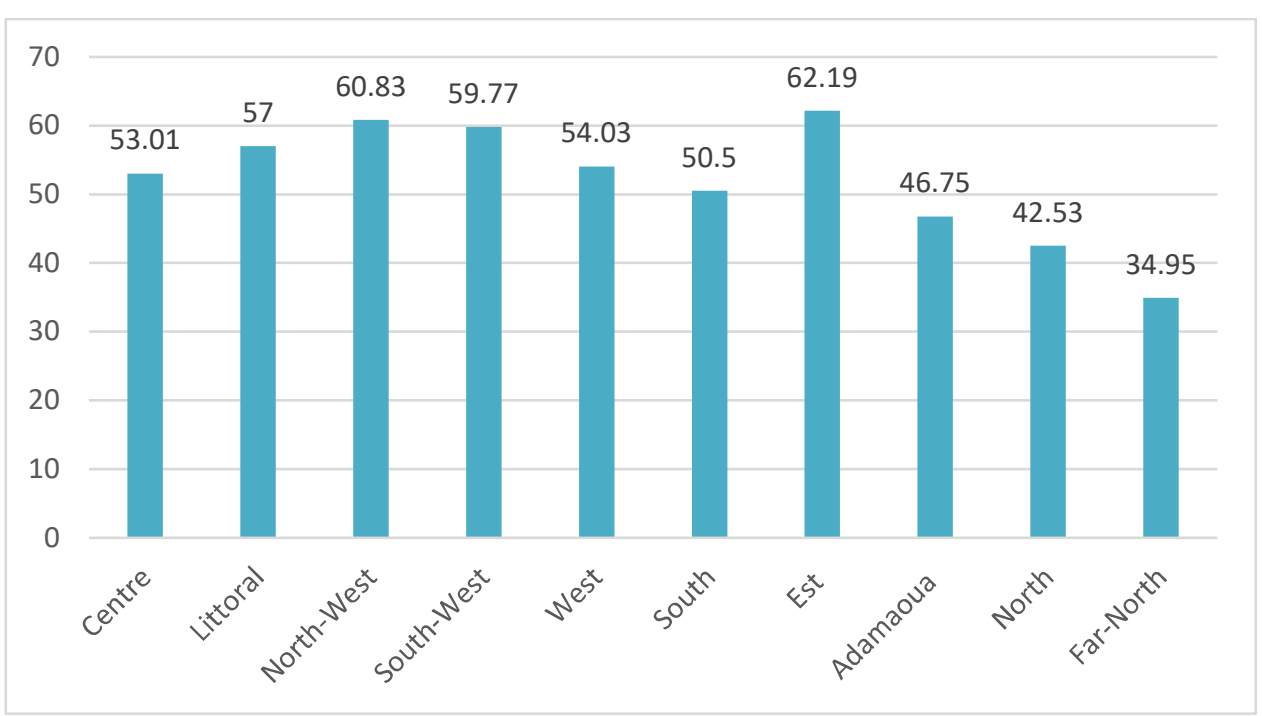

Figure 3: Success rate (\%) of the baccalaureate exam by region in 2018

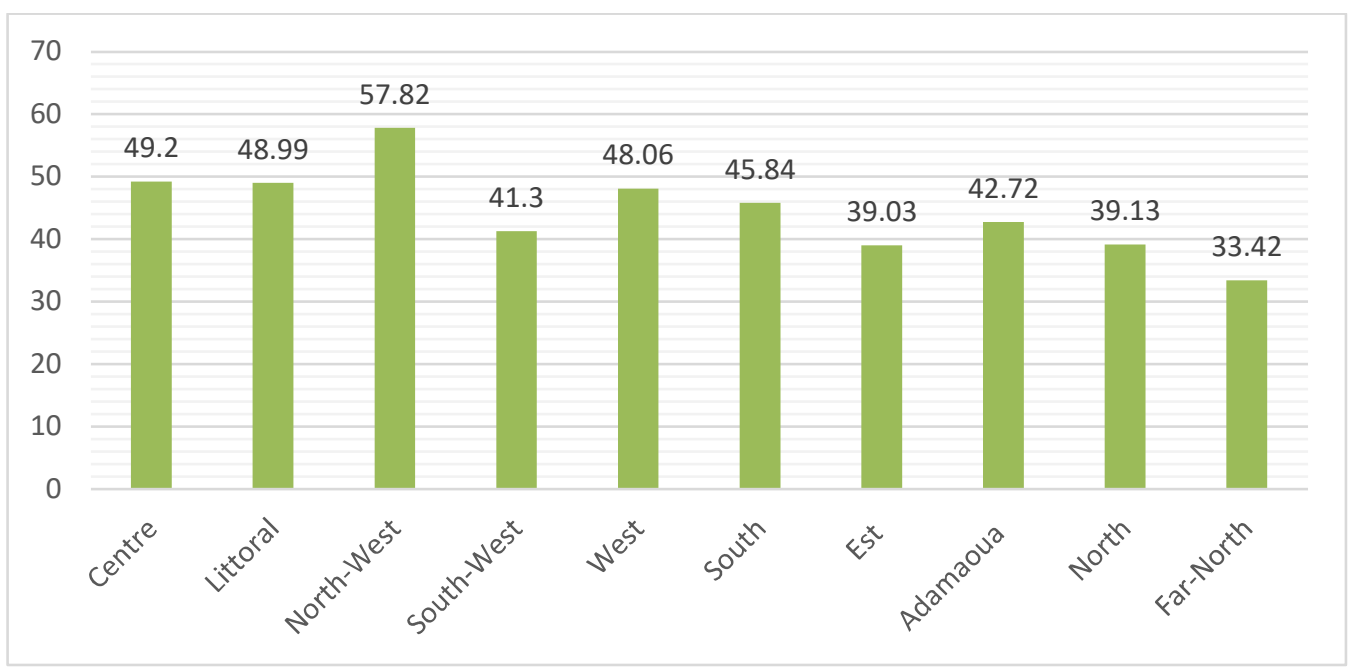

Figure 4: Success rate (\%) of the baccalaureate exam by region in 2017

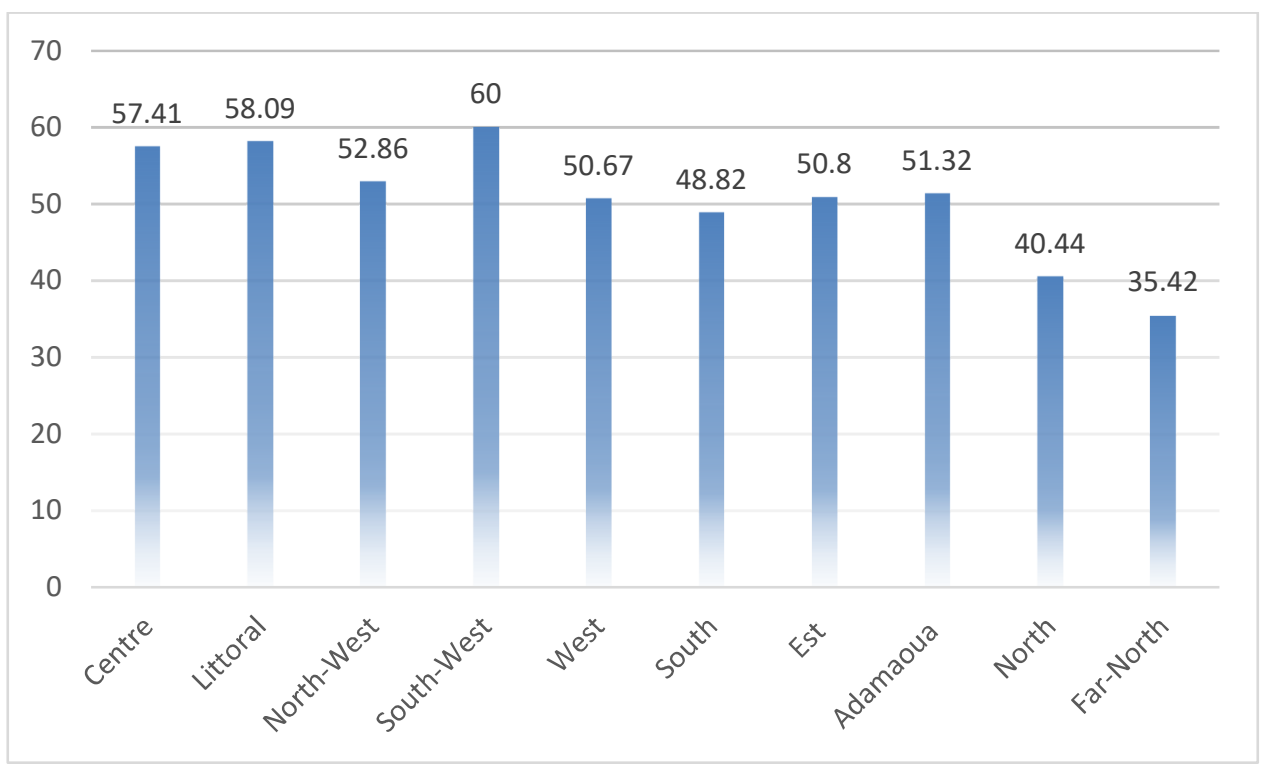

Figure 5: Success rate (\%) of the baccalaureate exam by region in 2016 
The above table and the three figures 3, 4, and 5 respectively show 2018, 2017, and 2016 statistics of the baccalaureate exam results of the general secondary education from 2018 back to 2016 (with an extension to 2015 in the table). They show that, out of the ten regions, the Far-North and the North ranked almost the top last, with Far-North always the last every year in the overall regional ranking. Only the Adamaoua region, also one of the three regions in the northern part of the country but bordering on the south, which often varies between medium and less performing regions. Students' performance in the Far-North and North region has never reached 50\% since 2015. Their highest success rates since 2015 is limited to 35.42 percent for the Far-North, and 49.07 for the North region.

\section{Policy addressing regional disparities regarding education in Cameroon}

The huge regional disparities gap between northern and southern regions, which has long been affecting the education sector in Cameroon has not caught enough the government attention to take appropriate measures in order to reduce it. Some policy sketches and strategies have been adopted to reduce regional and gender disparities in education, but disparities have not changed much. In 2000, for instance, the government had created the "Priority Education Zones" policy, referring to the disadvantaged regions lagging behind the national level (MINEDUB et al., 2013). This policy has somehow reduced the disparity in schooling concerning primary education, but has not achieved the expectations because the strategies set have not been implemented. For instance, the increase of the salary for teachers in priority areas, free housing, and the measures regarding their career have not been implemented. The provision of teaching and learning materials have not been effective.

In addition, in 2013, the adoption of a document called "Education Sector Strategy Paper" also devoted a big part to the disparities in education at all levels. This paper looks at the strategies to promote access, equity and quality, and good governance of education in order to solve the problems that the Cameroonian education system is facing, among which regional disparities. With regard to regional disparities, the renovation and increase of educational infrastructures, the increase of teachers and their retention in the disadvantaged regions, the involvement of local communities and the encouragement of private education in rural areas, positive discrimination regarding the resources' investment, are among others various measures that have been taken in the "Education Sector Strategy Paper" to promote equality and equity in the education sector (MINEDUB et al., 2013). However, it is to mention that the implementation of the policies in general, and strategies regarding education, in particular, remains a big challenge in Cameroon. Policies and strategies are, most of the time well formulated, but they are only kept on the papers. They have been rarely implemented. In reality, the lack of willingness and the slowness in solving problems are the main problems in Cameroonian. The measures mentioned above to address inequalities in education have long adopted, but nothing concrete is done to reduce the gap. The gap has been even widening recently due to the crisis that has been devastating in some regions.

\section{Policies experience from some selected countries addressing social disparities and policies responses}

Although social inequalities, especially geographical inequalities, are very high in developing countries, many developed countries also do not escape. Various policies have been developed around the world to eliminate those inequalities that hinder shared prosperity and the development of the countries as a whole. State governments, as well as international organisations, keep issuing policies and strategies to have fair and shared prosperity across the countries and the world. However, in most of the cases, these inequalities have not much changed. The reasons for those unsuccessful policies are either due to their:

(a) Inappropriateness such as quota distribution policies. According to a couple of studies, the countries that extensively apply quotas do not always achieve either better representation for underrepresented groups or an adequate level of social inclusion (Gerapetritis, 2016).

(b) The lack of sufficient financial support to raise or compensate the level of disadvantaged groups;

(c) A lack of real political will to address the problem;

(d) Or the difficulty to objectively define and apply social equality and equity.

Speaking of developing countries, social inequalities have always been a concern since the period of independences. For many of these countries, social equality meant national unity (Davies, 1986), and education was a sector par excellence to address that issue. In Nigeria, for instance, the creation of a fair and egalitarian society through education is one of the main national objectives. In Kenya, an equitable distribution of education inputs to every citizen was a primary objective in education. Regarding Tanzania, it emphasised the creation of socialism so as to tackle social inequality (Davies, 1986). In many countries, the worry of creating an equal and fair society was in the foreground of their agenda. Nevertheless, few countries have reduced inequalities. Many country's objectives to reduce inequalities, especially regional disparities, were simply a fiasco. Some studies show that correcting inequalities is somewhat better through a very high overall social welfare (such as in many Scandinavian countries and countries like New Zealand, Australia, Canada; among others) than extensive use of affirmative action or having constitutional provisions (Gerapetritis, 2016). 


\subsection{The United States}

Speaking of policies addressing inequalities, the US is considered as the birthplace of systematic positive discrimination measures (Gerapetritis, 2016), called affirmative action. The US has experienced large inequalities. Extensive relevant legislation and executive orders have been given rise. The inequalities in the US have been mainly based on the race, which is different from European countries where disparities regard mostly gender inequalities and in Africa with both regional and gender inequalities (except South Africa, where inequalities are also mainly based on race). After more than two centuries of enslavement and another century of racial discrimination imposed on minority groups such as African Americans, positive discrimination policies were enacted after Civil Right Movement in the 1950s and early 1960s (Sowell, 2004; Weisskopf, 2004). African American leaders, namely Martin Luther King, Abraham Lincoln, and others, have struggled a lot to push the US governments to take measures against black segregation. The Civil Right Act was issued and then followed by a series of executive orders promoting equal opportunities in employment and education. Weisskopf (2004) argued that affirmative action in favour of minorities was born in the US when the initial positive discrimination in its original meaning of guaranteeing legal and equal opportunity without granting any preferential treatment was not sufficient to address mistreatment towards minorities (African Americans, Hispanics and Native Americans).

Regarding education, the federal government issued a policy to abolish school separation and introduced affirmative action in university admissions. Affirmative action was used in the university admission because minority ethnic group's students received a low-quality education, with poor quality infrastructures and personnel. Thus, logically they could not compete with their 'white' counterparts. The governments and universities have introduced various affirmative action measures to ease the admission of minority applicants. For the candidates who meet basic criteria, the university added 20 points of bonus out of the total maximum points (the University of Michigan) in order to be admitted (Gerapetritis, 2016). Some Universities have a set number of percentages for minorities to be admitted. However, depending on the states and universities, these measures have relatively faced rigidities. Since then, affirmative action regarding minorities has been enacted but sooner contesting and even abolishing. There was a kind of repetition in issuing and abolishing. Many arguments rised against affirmative action. Many people think it is radically unfair. Many opted for a "colour-blind" policy. However, the policies regarding affirmative action still exist until now in many American institutions despite some contestations. Knowing the importance of such an action in education and society, especially the fact that among several affirmative action plans put in place, according to some surveys, no single one has been firmly and explicitly established yet. Several NGOs are engaged in promoting positive discrimination by launching research programs, lobbying, fundraising, and sponsoring in order to bring institutions to adhere to the idea (Gerapetritis, 2016).

\subsection{South Africa}

Like in the US, the inequalities in education, in public services, and in employment based on race have also been experienced in South Africa. Special policies have been taken against racial segregation, known as "Apartheid." The difference between the segregation in South Africa and the US is that in South Africa, the majority race was oppressed by the minority, and the compensation or positive discrimination policy aims at favouring the majority race (black). Before the adoption of democracy in 1994, the apartheid system excluded black people from political, economic, and educational participation (Gerapetritis, 2016). The country was divided into two parts: the white part was very developed, and that of black people was a real ghetto. The black population was subjected to many restrictions.

Regarding education, the state spent not only fewer resources on the education of not-whites than that of whites, but it also systematically prohibited black students from entering white educational institutions (Black, 1996). However, as said, after the restoration of democracy in 1994, followed by several denunciations and demonstrations against the Apartheid system, measures have been taken to establish social inclusion and a nondiscrimination society. The constitution stipulated that "we, the people of South Africa recognize the injustices of our past, honour those who suffered for justice and freedom in our land [...]. Believe that South Africa belongs to all who live in it, united in our diversity [...]. Lay the foundations for a democratic and open society in which government is based on the will of the people and every citizen is equally protected by the law" Gerapetritis (2016). In addition to what is stipulated in the constitution, affirmative action measures in favour of the black population in education and employment were enacted in order to compensate the past discrimination and ensure equality and fairness.

\subsection{China}

Like Cameroon, China is a country which presents a geographical diversity, both in terms of development and opportunities for education access, quality, and achievement. The Western areas, compared to the central part and especially to the eastern part, are very undeveloped. Aware of that, the Chinese government keeps issuing policies and strategies at the central level, provincial as well as local levels to assist western regions. The policy concerns both the development of infrastructures and the supply of human resources in underserved areas. The development 
of infrastructures or policy of urbanising rural areas aims at investing in educational infrastructures in order to reduce the development gap between developing and developed areas. Unlike the previous policies, which consisted of migrating rural schools to the cities, the new reform seeks to urbanize rural areas rather than to bring the rural population to the cities. The former system is judged less relevant for the socio-economic development of the country. "The action plan for Invigorating Education from 2003 to 2007, focused on the development of educational institutions, finance, human resource management, leadership skills, and the promotion of talents in the western regions" (Hawkins et al., 2008). According to some literature, since the launch of the new reform policy aiming to urbanise and covering about 900 million people by 2025 , today, many villages have become small cities.

Regarding the supply of human resources, it mainly concerns the recruitment of teachers in disadvantaged areas through special policies for teacher recruitment in rural areas (Guiake, 2018). The Chinese government has committed over the last decade to improve teaching quality in rural regions so as to close the education gap between rural and urban (Yiu and Adams, 2013). To this end, many policies deal with strategies on how to recruit more qualified teachers to teach in rural schools. For example, college students and urban school teachers are encouraged to volunteer-teach in rural areas, and particular posts are designed to attract college graduates to teach in poor rural schools in west China (MOE, 2004, 2006, 2007). Several training campaigns specifically for rural school teachers, were also launched nationwide. Moreover, in order to attract more teachers in disadvantaged areas, teachers, and educational administrators working in those areas are pecuniary better treated than their counterparts in urban areas (Guiake, 2018).

In addition to those policies regarding the urbanization of rural areas, the development of educational infrastructures, and special treatment for teachers' recruitment in disadvantaged areas, some strategies are putting in place to treat students fairly from different backgrounds and areas. There is, for instance, the score cutoff for students from disadvantaged areas or minority groups in national examinations such as college entrance examinations in order to ensure the equity access into higher education. According to Hawkins et al., (2008), several policy reforms have been initiated to focus on the issue of preferential treatment for disadvantaged population, such as financial assistance (tuition fees, government-subsidized student loan scheme, the state fellowship and scholarship program), and other privileges to promote equity in education. The document indicates that the Chinese government is striving to eliminate existing inequalities in education through various initiatives and methods.

\subsection{Ghana}

Experiencing the same situation of geographical inequalities in education like in many African countries, Ghana has developed some policies aiming at addressing the challenge of disparities in education, especially with regards to secondary school. It has focused on equal opportunities for access to education between disadvantaged areas and advantaged areas through the so-called Growth and Poverty Reduction Strategy. The aim is to provide each district, regardless of its geographical situation, a school, similar to the leading schools in the country in order to ensure equity and quality in the education system (Higgins, 2009). Appropriate infrastructures and academic requirements are the main contents of upgrading those schools. The program is broken down into several phases with annual progress assessment reports. Ghana is one of the African countries which is struggling to address inequalities not only in education but also in many other domains. However, the analysis of that particular strategy of the Ghanaian government regarding the offer of the same school's infrastructures and academic requirements in every district is seen as equality, not as equity. It might have an impact in the long term if things are going on in that way because the already existing gap differences will still exist. That is why equity practices are much better to lift disadvantaged areas to be on the same line with other more developed areas so as to create shared prosperity and development.

\section{Discussion and Concluding Remarks}

Regional inequalities, both in education and other domains in developing countries, are very worrisome. The gap difference is too wide to the point that it sometimes gives an impression that areas do not belong to the same country. In Cameroon, the three northern regions, due to the main reason of unfair and unequal distribution of the state assets, added to some reasons such as the scarcity of rainfall, their distance away from the coastal region, and the terrorist crisis are subjects of inequalities in the country. Many sources, namely international organisation reports, annual releases of secondary schools' official examination results, and the national institute of statistics of Cameroon, have noted the huge educational discrepancies between the northern and southern regions. The distribution of teachers, educational infrastructures, teaching, and learning materials are always in lack in the northern regions while other regions sometimes possess in surplus. That unequal distribution is mostly due to the extreme centralisation of the education system in which regional level does not receive much attention. To this mismanagement, the 2012 world bank report noted a necessity for a reform of governance regarding the relevance of improving teacher management, equitable distribution of resources, effective monitoring of budgets and 
expenditure, and an establishment of a public transparency system to promote good governance (Guiake, 2018). In addition to the need for reforming educational governance, it should have room to address educational inequalities and inequities through special policies for the aim of promoting shared prosperity among all citizens. Special policies addressing inequalities in education could help students from underserved regions to get the same opportunity that others have. Special policies towards less developed regions, such as the northern regions, will narrow the huge educational gap between them and the other regions. The purpose of any good educational policy is to define an educational system consistent with the type of society that we want to create. If we want to have a shared prosperous society, we need to have a good educational and social policy. There is a close relationship between education and society in which we live. Educational policy plays a vital role in the kind of society we want to shape. According to Bloome et al., (2018), the children of high-income parents often become high-income adults, while low-income peers often become low-income adults. Similarly, communities or parents educational background greatly affect the education of their children. Such inequality's reproduction signifies that if nothing is done regarding educational policy to address educational or social disparities, advantaged people will remain advantaged and disadvantaged will stay disadvantaged, and inequality gap will continue to be enlarged, which, too often leads to the social tensions and crises. For Dardanoni et al. (2004) cited in (Checchi \& Peragine, 2005), parents educational background affects children's basic education, cognitive abilities, provision of social connections and formation of beliefs and skills in children. To Bloome et al., (2018), educational-based disparities have increased in recent decades, and intergenerational inequalities would persist. It is through an equal and fair educational policy that intergenerational inequalities can be disappeared.

For this reason, and based on various policies addressing inequalities examined in this study, the practice of regional quotas distribution in the public service might be good in maintaining social peace, but it cannot respond to regional inequalities. It does not solve inequalities in education in Cameroon. Additional policies should address the crux of the inequalities rather than partial solutions. The northern regions are far less advanced in schooling. They constitute the hubs of poverty in Cameroon. Hence, as said, the government should address through special policies, with commitment, the origins of disparities between regions by heavily investing in underserved regions so as to effectively address the challenge of inequalities in education.

\section{Funding:}

The publication fee of this paper is supported by the "Open Research Fund of College of Teacher Education, Zhejiang Normal University" (No. JYKF20037); and "Zhejiang Province Philosophy \& Social Science Discipline, Major Subsidised Project 2019” (No 19YSXK05ZD).

\section{References}

Black, P. A. (1996). Affirmative Action in South Africa Rational Discrimination According to Akerlof. The South African Journal of Economy, $0(1), 38-43$.

Bloome, D., Dyer, S., \& Zhou, X. (2018). Educational Inequality, Educational Expansion, and Intergenerational Income Persistence in the United States. American Sociological Review, 83(6), 1215-1253. Retrieved from https://journals.sagepub.com/doi/pdf/10.1177/0003122418809374

Castelli, L., Ragazzi, S., \& Crescentini, A. (2012). Equity in education : a general overview. Procedia - Social and Behavioral Sciences, 69, 2243-2250. https://doi.org/10.1016/j.sbspro.2012.12.194

Checchi, D., \& Peragine, V. (2005). Regional Disparities and Inequality of Opportunity: The Case of Italy (No. 1874). Bonn, Germany. Retrieved from http://hdl.handle.net/10419/33655\%0AStandardNutzungsbedingungen:

Davies, L. (1986). Policies on Inequality in the Third World: Dependency or Autonomy? British Journal of Sociology of Education, 7(2), 191-204.

Gerapetritis, G. (2016). Affirmative Action Policies and Judicial Review Worldwide. (M. Sellers \& J. Maxeiner, Eds.). New York: Springer International Publishing, Switzerland.

Guiake, M. (2018). Comparative Study of Teacher Recruitment and Selection Practices in Public Secondary School in Cameroon and China. Master's thesis. Zhejiang Normal University.

Guiake, M., \& Zhang, T. (2019). Higher Education' s Curriculum and Challenges of the 21 st Century: The Case Study of Cameroonian Public Universities. Journal of Education and Practice, 10(18), 120-127. https://doi.org/10.7176/JEP

Hawkins, J. N., Jacob, J. W., \& Li, W. (2008). Higher education in China: Access, Equity and Equality. In M. Mason \& M. Bray (Eds.), Inequality in Education: Comparative and International Perspectives. Hong Kong: Comparative Education Research Centre.

Higgins, K. (2009). Regional Inequality and Secondary Education in Ghana (No. Policy Brief No 1). Ghana.

Jones, H. (2009). Equity in development, Why it is important and how to achieve it (No. 311). London.

Kazé, B. (2019, April 7). Cameroun-Fonction Publique:600 fonctionnaires traduits au conseil de discipline dans la region de l'Extreme- Nord[Cameroon-Civil service : 600 civil servants translated to the Disciplinary 
Board in the Far North Region]. Cameroon-Info.Net. Retrieved from http://www.camerooninfo.net/article/cameroun-fonction-publique-600-fonctionnaires-traduits-au-conseil-de-discipline-dans-laregion-de-338115.html

MINEDUB, MINESEC, MINEFOP MINESUP, MINEPAT, M. (2013). Document de Stratégie du Secteur de l'Education et de la Formation.

Mullen, E., \& Okimoto, T. (2015). Compensatory Justice. In The Oxford Handbook of Justice in the workplace. Oxford, New York: Oxford University Press.

OECD. (2012). Equity and Quality in Education: Supporting Disadvantaged students and schools. Retrieved from http://dx.doi.org/10.1787/9789264130852-

Rew, J. (2008). Provincial, Ethnic, and Gender Disparities in Education: A Descriptive Study of Vietnam. In Inequality in Education: Comparative and International Perspectives.

Som-I, J.-D. (2018). L'équilibre régional au Cameroun:Politique d'équité sociale ou dérive ethnique [The regional equilibrium in Cameroon: Social equity policy or ethnic drift]. Transylvanian Review, XXVII.

Sowell, T. (2004). Affirmative Action Around the World, An Empirical Study. (J. Johnson, Ed.). New Haven \& London: Library of Congress Cataloging-in-Publication Data.

Stewart, F. (2013). Approaches towards Inequality and Inequity: Concepts, measures and policies (No. No.2013$01)$. Florence.

UNDP. (2016). United Nation in Cameroon.

UNESCO. (2017). UNESCO moving forward the 2030 Agenda for Sustainable Development. Paris, France.

UNESCO. (2019a). Leading SDG 4 - Education 2030. Retrieved July 17, 2019, from https://en.unesco.org/themes/education2030-sdg4

UNESCO. (2019b). Teachers. Retrieved July 18, 2019, from https://en.unesco.org/themes/teachers

Weisskopf, T. E. (2004). Affirmative Action in the United States and India economics within social theory (first ed). London and New York: Routledge, Taylor \& Francis group.

World bank. (2016). Republic of Cameroon Priorities for ending poverty and boosting shared prosperity. Retrieved https://www.researchgate.net/publication/304581098_Republic_of_Cameroon_Priorities_for_Ending_Pov erty_and_Boosting_Shared_Prosperity_Systematic_Country_Diagnostic

World bank. (2018). Combined Project Information Documents / Integrated Safeguards Datasheet (PID / ISDS).

Yiu, L., \& Adams, J. (2013). Reforming Rural Education in China: Understanding Teacher Expectations for Rural Youth, 993-1017. https://doi.org/10.1017/S0305741013001136

Yodou Sibeudeu, A. P. (2011). Justice politique et prévention des conflits dans les sociétés pluriethniques: cas de la politique de l'équilibre régional au Cameroun [Political justice and conflict prevention in multi-ethnic societies: cases of regional balance policy in Cameroon]. Université catholique d'Afrique centrale. Retrieved from https://www.memoireonline.com/11/13/7922/m_Justice-politique-et-prevention-desconflits-dans-les-societes-pluriethniques-cas-de-la-politiqu28.html 